EVIDENCE BASED PUBLIC HEALTH POLICY AND PRACTICE

\title{
Once a week is not enough: effects of a widely implemented group based exercise programme for older adults; a randomised controlled trial
}

\author{
M Stiggelbout, D Y Popkema, M Hopman-Rock, M de Greef, W van Mechelen
}

J Epidemiol Community Health 2004;58:83-88

See end of article for authors' affiliations

\section{Correspondence to:} Dr M Stiggelbout, TNO

Prevention and Health PO-Box 2215, 2301 CE Leiden, Netherlands; M.Stiggelbout@pg.tno.nl

\begin{abstract}
Objectives: To determine the effects of gymnastics on the health related quality of life (HRQoL) and functional status of independently living people, aged 65 to 80 years. Gymnastics formed part of the More Exercise for Seniors (MBvO in Dutch) programme, a group based exercise programme for older adults in the Netherlands. It has been widely implemented since 1980.

Design: Randomised controlled trial with pretest and post-test measurements.

Intervention: The exercise programme given by experienced instructors lasted 10 weeks and was given weekly ( $\mathrm{MBrO1} ; \mathrm{n}=125$, six groups) or twice weekly (MBvO2; $n=68$, six groups). The control group $(n=193)$ was offered a health education programme.

Setting: Community dwelling of older people, with a comparatively low level of fitness as assessed with the Groningen Fitness test for the Elderly.

Results: No significant effects were found on the HRQoL (Vitality Plus Scale, TAAQoL, and RAND-36) and the functional status (Physical Performance Test and the Groningen Activity Restriction Scale). The MBrO2 group, with a low level of physical activity at baseline, showed the only improvement found on the Vitality Plus Scale $(F=4.53 ; p=0.01)$.

Conclusions: $\mathrm{MBvO}$ gymnastics once a week did not provide benefits in HRQoL and functional status after 10 weeks. However, participants with a low level of physical activity may benefit from $\mathrm{MBvO}$ gymnastics if they participate twice a week. To improve the health of the general public, sedentary older adults should be recruited and encouraged to combine $\mathrm{MBrO}$ with the health enhancing physical activity guidelines.
\end{abstract}

$\mathrm{T}$ here is clear evidence of the benefits of exercise programmes for older people. $^{12}$ Exercise plays an important part in increasing the quality of life of the older adult, by improving physiological and psychological function, which helps to maintain personal independence and reduces the demands for short term and long term care services. ${ }^{3}$ However, there is no consensus on the amount of gain in this area. ${ }^{4}$ Recent guidelines for health enhancing physical activity emphasise the importance of moderate physical activity. ${ }^{5}$ Moderate physical activity is often more appropriate for older people because the chance of getting injured is reduced, and their continued participation in more vigorous exercise is more likely. More Exercise for Seniors ( $\mathrm{MBvO}$ in Dutch) is a moderately intensive exercise programme, offered once a week, that was started on an experimental basis in 1966 and has been implemented widely since 1980. It was designed specifically for people of 65 years and older. The goal of $\mathrm{MBVO}$ is to promote optimal functioning in older adults, not only physically, but also mentally and socially. ${ }^{6}$ Currently, more than 300000 older people over 65 years of age participate weekly in various types of $\mathrm{MBvO}$ programmes. The basic form of $\mathrm{MBvO}$ consists of gymnastics once a week. Until now, no study has been carried out on the effectiveness of $\mathrm{MBvO}$ in terms of health gain. In this article, the effects of $\mathrm{MBvO}$ gymnastics on health related quality of life (HRQOL) and functional status of independently living participants (age 65 to 80 years) are evaluated. HRQoL includes several dimensions, such as cognitive, social, physical, and emotional functioning. ${ }^{1}$ Functional status refers to a person's ability to perform tasks and to fulfil social roles associated with daily living, over a broad range of complexity. ${ }^{1}$

\section{METHODS}

This section and the result section are ordered following the criteria of the CONSORT statement for reporting randomised trials. ${ }^{7}$

\section{Design}

The study was a multicentre randomised controlled trial, with a cross over design and pretest and post-test evaluations. Subjects were randomised to an experimental group and a control group. The participants in the experimental group were divided into two groups participating once a week $(\mathrm{MBvOl})$, or twice a week $(\mathrm{MBvO} 2)$. The control group received a health education programme. The trial was designed to detect a minimum difference in effect size of $0.25-0.30$ with $80 \%$ power at $\alpha=0.05 .^{8}$ According to this calculation 360 participants were needed (180 in the experimental group and 180 in the control group). Randomisation took place before baseline measurements were taken. In the second phase, after the post-test evaluation, the control group was also offered either one of the two exercise programmes and the experimental group was offered the health education programme. The medical ethics testing committee of both TNO Prevention and Health and the University of Groningen approved the study protocol.

Abbreviations: $\mathrm{MBvO}$, More Exercise for Seniors; HRQoL, health related quality of life; PPT, Physical Performance Test; GARS, Groningen Activity Restriction Scale 


\section{Key points}

- More exercise for seniors ( $\mathrm{MBvO}$ ) is the most widely implemented exercise programme for older adults in the Netherlands, usually offered once a week.

- For benefits of functional status and health related quality of life, once a week participation is insufficient.

\section{Recruitment procedure and study population}

The Groningen Active Living Model (GALM) was used to recruit subjects. ${ }^{9}$ About 4600 older adults-selected at random from the municipal registers of the cities of Emmen, Leiden, and Roden (in the Netherlands)—received a written invitation for a screening procedure and were visited at home by a member of the local project team. Door to door approaches have been shown to increase participation in previous studies. ${ }^{9}$ During this visit, potential participants were screened using a short questionnaire based on the criteria of the public health recommendations for physical activity. ${ }^{5}$ People who were not sufficiently active according to these criteria and who met the inclusion criteria (that is, age 65 to 80 years and living independently) were invited to participate in a fitness test. In total 721 subjects participated in this test, which consisted of a performance based fitness test (Groningen Fitness test for the Elderly ${ }^{10}$ ) and a health appraisal questionnaire (PAR-Q) applied to identify participants for whom exercise might be risky. The subjects whose test scores were below the median on the walking endurance test were invited to participate in the trial. To compensate for the expected drop out, 26 extra participants were invited. Figure 1 shows a flow chart of the study. Written informed consent was obtained from each subject.

\section{Intervention}

$\mathrm{MBvOl}$ participants followed the exercise class once a week and $\mathrm{MBvO} 2$ participants twice a week. All exercise sessions took place at a community centre. The sessions for both groups were comparable regarding the type of exercise, duration, and intensity. The intervention lasted 10 weeks. Each exercise class consisted of 10-18 participants and each exercise session lasted 45 minutes and consisted of three stages: 5 minutes warm up, 35 minutes of light aerobic exercises, mainly muscle strengthening exercise and exercises aimed at improving coordination, followed by a five minute cool down period. The lessons took place in a gymnasium and were supervised by a trained and experienced instructor. At the end of each exercise session, participants drank a cup of coffee together as a social event.

The control group followed a health education programme designed to provide attention, social interaction, and health education on lifestyle aspects (excluding information about the benefits of physical activity, exercise, and nutrition). Participants were assigned to groups of 15-25 persons. During the intervention period control group participants received a monthly 1.5 hour education session led by a trained instructor.

\section{Assessment of HRQOL and functional status}

Trained interviewers interviewed the subjects to assess HRQOL and functional status. Pretest and post-test interviews were held at the subjects own home (in Leiden) and at two municipal facilities (in Emmen/Roden).

Three instruments were used to measure HRQoL, namely the Vitality Plus Scale $\left(\mathrm{VPS}^{11}\right)$, the RAND-36, ${ }^{12}$ and the TNO

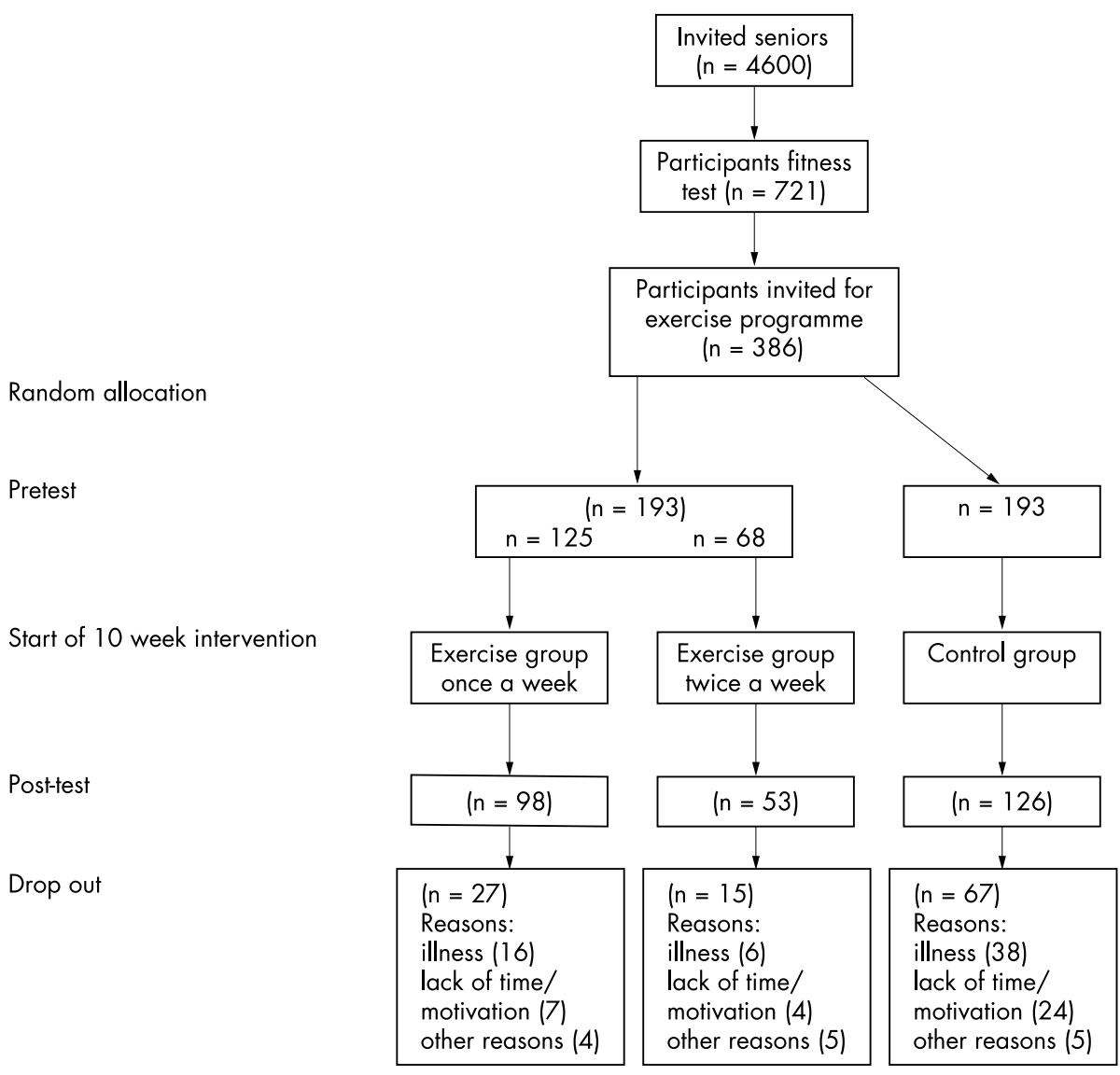

Figure 1 Flow chart of the study. 
Leiden Academic Hospital Adult Quality of Life questionnaire (TAAQOL). ${ }^{13}$ The VPS consists of questions concerning sleep, tiredness, appetite, obstipation, pain, energy, morning stiffness, relaxation, and feeling well (reliability: Cronbach's $\alpha$ $0.81^{11}$ ). The RAND-36 is a multi-dimensional health questionnaire, which has been translated into Dutch. ${ }^{14}$ It consists of nine subscales. In this study five subscales were used: vitality (reliability: Cronbach's $\alpha 0.82^{12}$ ), pain (Cronbach's $\alpha$ 0.88 ), mental health (Cronbach's $\alpha 0.85$ ), general feeling of health (Cronbach's $\alpha 0.81$ ), and change in health status (a one item subscale: no $\alpha$ available). The TAAQOL measures health problems in relation to the way people experience these as problems. The TAAQOL was developed specifically for adults to measure the effects of interventions. It consists of 12 dimensions, which may also be used separately. The subscales social contact (reliability: Cronbach's $\alpha 0.85^{13}$ ) and cognition (Cronbach's $\alpha$ 0.87) were used. Functional status was evaluated with the short form (7 item scale) Physical Performance Test (PPT; Cronbach's $\alpha$ 0.79). ${ }^{15}$ The PPT consists of seven tasks of daily living.

Subjective functional independence was measured with the Groningen Activity Restriction Scale (GARS). The GARS consists of 18 questions about daily activities, and the sum score provides information on the level of difficulty a person experiences in care taking and household activities. ${ }^{16}$
Background information on age, gender, marital status, housing situation, and education was obtained during the interview. Body weight and height were measured. Body mass index (BMI) was calculated by dividing weight (in kilograms) by the square of height (in $\mathrm{m}^{2}$ ).

Physical activity was measured using a questionnaire especially designed for use in older people (Spearman correlation with objective measures: $\rho=0.89) .{ }^{17}$ The questions cover three areas, namely, household activities (mean score of 10 items), sports activities (intensity, hours per week, and period of the year for two sports maximum), and leisure time activities (such as knitting, sewing, and reading; intensity, hours per week, and period of the year, six activities maximum). Walking, cycling, and gardening were regarded as sports activities. For the purpose of this study only the household and sports activity questions were used. The sports activity score was calculated by using a formula with weight for intensity, hours per week, and months per year (this is explained in more detail in Voorrips et al, ${ }^{17}$ resulting in an index from zero to $\infty$ (level of physical activity by Voorrips $e t$ al $^{17}$ for a research group of 29 older adults is $13.6 \pm 6.8$ ( $\min 1.2-\max 31.4)$.

Other lifestyle components included in the questionnaire were drinking alcohol and smoking. Chronic diseases were characterised using the list of chronic diseases used in the national health survey. ${ }^{18}$

Table 1A Background characteristics of subjects at randomisation

\begin{tabular}{|c|c|c|c|c|c|c|c|c|c|}
\hline Variables & MBvOl & $(n=98)$ & MBvO2 & $(n=53)$ & Control group & $(n=126)$ & Total & $(n=277)$ & p Value \\
\hline Mean age in years $(y, S D)$ & 71.6 & $(4.0)$ & 71.5 & (4.1) & 70.3 & $(4.0)$ & 71.0 & (4.1) & $0.05^{*}$ \\
\hline $\mathrm{BMI}\left(\mathrm{kg} / \mathrm{m}^{2}, \mathrm{SD}\right)$ & 27.1 & (3.5) & 26.8 & (3.6) & 28.0 & (4.1) & 27.4 & (3.8) & $0.11^{*}$ \\
\hline Gender $(\%, n)$ & $\%$ & n & $\%$ & n & $\%$ & n & $\%$ & n & $0.12 \dagger$ \\
\hline $\begin{array}{l}\text { male } \\
\text { female }\end{array}$ & 30 & (29) & 45 & & & & & (103) & \\
\hline \multirow{7}{*}{$\begin{array}{l}\text { Marital status }(\%, \mathrm{n}) \\
\text { married (living together) } \\
\text { unmarried (living together) } \\
\text { divorced } \\
\text { widowed } \\
\text { never lived together }\end{array}$} & 70 & (69) & & & 60 & (76) & 63 & (174) & \\
\hline & & & & & & & & & $0.49 \dagger$ \\
\hline & 77 & (75) & 72 & (38) & 66 & (83) & 71 & (196) & \\
\hline & 1 & (1) & & & 1 & (1) & 1 & (2) & \\
\hline & 3 & (3) & 2 & (1) & 2 & (3) & 3 & (7) & \\
\hline & 17 & (16) & 26 & (14) & 26 & (32) & 23 & (62) & \\
\hline & 2 & (2) & & & 5 & (6) & 3 & (8) & \\
\hline \multirow{4}{*}{$\begin{array}{l}\text { Level of education }(\%, n) \\
\text { high } \\
\text { middle } \\
\text { low }\end{array}$} & & & & & & & & & $0.99 \dagger$ \\
\hline & 5 & (5) & 13 & (7) & 8 & (10) & 8 & (22) & \\
\hline & 41 & (40) & 43 & (22) & 41 & (51) & 41 & (113) & \\
\hline & 54 & (52) & 45 & (24) & 51 & (64) & 51 & (140) & \\
\hline \multirow{4}{*}{$\begin{array}{l}\text { Housing situation }(\%, n) \\
\text { multi-storey house } \\
\text { apartment building } \\
\text { service flat }\end{array}$} & & & & & & & & & $0.34 \dagger$ \\
\hline & 66 & (64) & 51 & (27) & 62 & (77) & 61 & (168) & \\
\hline & 33 & (32) & 49 & (26) & 37 & (46) & 38 & (104) & \\
\hline & 1 & (1) & & & 2 & (1) & 1 & (3) & \\
\hline
\end{tabular}

Table 1B Lifestyle characteristics of subjects at randomisation

\begin{tabular}{|c|c|c|c|c|c|c|c|c|c|}
\hline Variables & MBvOl & $(n=98)$ & $\mathrm{MBvO2}$ & $(n=53)$ & $\begin{array}{l}\text { Control } \\
\text { group }\end{array}$ & $(n=126)$ & Total & $(n=277)$ & p Value \\
\hline \multicolumn{10}{|l|}{ Life style factors } \\
\hline Household activities & 1.92 & $(0.57)$ & 1.93 & $(0.51)$ & 1.98 & (0.53) & 1.95 & (0.59) & $0.72^{*}$ \\
\hline Sports activities $\ddagger$ & 3.33 & (3.79) & 4.36 & $(4.98)$ & 3.71 & $(4.87)$ & 3.70 & (4.54) & $0.42^{*}$ \\
\hline Total household/sports actł & 5.26 & (3.92) & 6.29 & $(4.87)$ & 5.69 & $(4.87)$ & 6.65 & (4.64) & $0.42^{*}$ \\
\hline Smoking $(\%, \mathrm{n})$ & $\%$ & $\mathrm{n}$ & $\%$ & $\mathrm{n}$ & $\%$ & $\mathrm{n}$ & $\%$ & $\mathrm{n}$ & $0.027 \dagger$ \\
\hline yes & 10 & (10) & 21 & (11) & 11 & (14) & 13 & (35) & \\
\hline no, formerly yes & 41 & (40) & 53 & $(28)$ & 55 & (69) & 50 & (137) & \\
\hline no, never & 49 & (47) & 26 & (14) & 34 & $42)$ & 38 & (103) & \\
\hline Alcohol $(\%, \mathrm{n})$ & & & & & & & & & $0.73+$ \\
\hline yes, maximal 5 glasses weekly & 39 & (38) & 34 & (18) & 35 & (44) & 36 & $(100)$ & \\
\hline yes, 6-10 glasses weekly & 17 & (16) & 23 & (12) & 17 & (21) & 18 & (49) & \\
\hline yes, 11-21 glasses weekly & 4 & (4) & 11 & (6) & 7 & (9) & 7 & (19) & \\
\hline yes, more than 21 glasses weekly & 1 & (1) & & & 2 & $(2)$ & 1 & (3) & \\
\hline no & 39 & (38) & 32 & (17) & 39 & (49) & 38 & (104) & \\
\hline
\end{tabular}


Table 2 Summary of the RAND-36 items, TAAQOL and Vitality Plus Scale, the GARS and the Physical Performance Test (PPT 7-items) (means and standard deviations) for $\mathrm{MBrO} 1, \mathrm{MBrO} 2$ and control group

\begin{tabular}{|c|c|c|c|c|c|c|c|c|}
\hline \multirow[b]{3}{*}{ Variables } & \multirow{2}{*}{\multicolumn{2}{|c|}{ MBvOl }} & \multirow{2}{*}{\multicolumn{2}{|c|}{$\mathrm{MBvO2}$}} & \multirow{2}{*}{\multicolumn{2}{|c|}{ Control group }} & \multirow{2}{*}{\multicolumn{2}{|c|}{$\frac{\text { Multiple analysis of variance }}{\text { Group x Time interaction }}$}} \\
\hline & & & & & & & & \\
\hline & $\begin{array}{l}\text { Pretest } \\
(n=98)\end{array}$ & $\begin{array}{l}\text { Post-test } \\
\text { (n=98) }\end{array}$ & $\begin{array}{l}\text { Pretest } \\
(n=53)\end{array}$ & $\begin{array}{l}\text { Post-test } \\
(n=53)\end{array}$ & $\begin{array}{l}\text { Pretest } \\
(n=126)\end{array}$ & $\begin{array}{l}\text { Post-test } \\
(n=126)\end{array}$ & $F$ & p Value \\
\hline \multicolumn{9}{|l|}{$\begin{array}{l}\text { Health status, HRQoL } \\
\text { RAND- } 36 \text { scales }\end{array}$} \\
\hline Vitality & $70.1(17.5)$ & $67.1(17.3)$ & $71.2(18.2)$ & $70.0(18.5)$ & $68.3(18.0)$ & $67.8(17.9)$ & 0.67 & 0.51 \\
\hline Pain*" & $77.3(21.7)$ & $79.8(20.4)$ & $85.4(17.5)$ & $83.6(21.8)$ & $81.0(19.9)$ & $83.2(19.8)$ & 0.97 & 0.38 \\
\hline Mental health & $77.1(15.0)$ & $77.1(16.4)$ & $80.0(13.3)$ & $77.9(17.8)$ & $76.8(17.9)$ & $77.7(16.7)$ & 0.93 & 0.40 \\
\hline General feeling of health & 63.8 (17.7) & $63.4(16.0)$ & $63.9(16.0)$ & $63.9(15.7)$ & $63.3(15.0)$ & $63.0(15.8)$ & 0.01 & 0.99 \\
\hline $\begin{array}{l}\text { Change in health status } \\
\text { TAAQOL scales }\end{array}$ & $47.7(21.2)$ & $49.0(19.2)$ & $50.5(18.7)$ & 49.5 (14.3) & $50.8(18.6)$ & $49.4(15.5)$ & 0.59 & 0.56 \\
\hline Social contacts & $86.3(17.5)$ & 83.4 (19.2) & $83.6(16.9)$ & $80.2(18.6)$ & $86.4(17.8)$ & $86.1(18.6)$ & 0.53 & 0.59 \\
\hline Cognition & $75.8(23.3)$ & $74.8(23.0)$ & $78.2(23.0)$ & $77.0(22.5)$ & $75.8(22.1)$ & $77.7(21.2)$ & 0.91 & 0.40 \\
\hline $\begin{array}{l}\text { Vitality Plus Scale } \\
\text { Functional status }\end{array}$ & $39.32(6.31)$ & $39.59(6.53)$ & $39.33(6.54)$ & $40.38(7.06)$ & $39.54(6.54)$ & $39.80(6.65)$ & 0.69 & 0.50 \\
\hline GARS & $20.23(3.68)$ & $20.12(3.16)$ & $19.81(3.75)$ & $19.31(2.63)$ & $20.15(3.66)$ & $20.33(3.68)$ & 1.09 & 0.34 \\
\hline PPT-7 score (0-28) & $24.24(2.82)$ & $25.33(1.94)$ & $24.75(2.48)$ & $25.43(1.43)$ & $24.31(2.87)$ & $24.66(2.27)$ & 2.65 & 0.07 \\
\hline
\end{tabular}

\section{Statistical analyses \\ Assignment}

All participants were allocated to the experimental or control condition at random. The intervention group participants were divided into two groups: $\mathrm{MBvOl}$ (participating once a week) and $\mathrm{MBvO} 2$ (participating twice a week). Participants who were not willing or able to participate twice a week were permitted to participate once a week.

\section{Analyses}

The analyses were carried out in two stages. In the first stage, the randomised groups were analysed, with the exercise groups $\mathrm{MBvOl}$ and $\mathrm{MBvO} 2$ being combined to form one exercise group score. In the second stage, the analyses were carried out for the two experimental groups (MBvOl and $\mathrm{MBvO2}$ ) separately. Descriptive statistics (Kruskal-Wallis one way analysis of variance with Tukey $\beta$ for interval data and $\chi^{2}$ tests for nominal data) were used for the background data.

Repeated measures analysis of variance was used to test for significant time $\mathrm{x}$ group interactions between the experimental group and control group and between the three groups ( $\mathrm{MBvO1}, \mathrm{MBvO2}$, and the control group) at a 0.05 level of significance (two sided). If there was a difference between groups on specific parameters at baseline, the parameter was used as covariate in the analysis. Post hoc tests were carried out using Tuckey $\beta$. In the analyses only data were included of participants who completed at least $50 \%$ of the exercise sessions (MBvOl $\geqslant 5$ sessions; $\mathrm{MBvO} 2 \geqslant 10$ sessions). To facilitate the interpretation of the results, effect sizes, calculated according to the method of Cohen, ${ }^{8}$ are also reported, using the differences between scores. The effect size is computed by dividing the difference between the means of the experimental and the control group, by a sample size weighted average of the standard deviations of the scores in the two groups. An effect size of 0.2 is regarded as a small effect, 0.5 as a medium sized effect, and 0.8 as a large effect. ${ }^{8}$

Statistical analysis was performed with the Scientific Package of Social Sciences (SPSS) version 10.0.

\section{Blinding}

Data were collected by trained staff, blinded to the treatment assignments. During the fitness tests, and the interviews, the participants were requested not to mention to which group they were assigned.

\section{RESULTS}

In total, data for 277 participants were analysed (fig 1). A total of 109 of the participants dropped out during the 10 weeks (fig 1).

\section{Background variables}

There was a small-but significant-difference in age between the experimental group and the control group (table 1A). However, age was not associated with the outcome variables and was therefore not used as covariate. There were no differences between the MBvO groups and the control group for BMI, gender, marital status, the level of education, and the housing situation at baseline (table lA).

\section{Lifestyle factors}

There were no differences in the level of physical activity between the experimental group(s) and control group at baseline (table 1B). There were significantly more smokers in

Table 3 Summary of health related quality of life outcomes for intervention and control groups by Vitality Plus Scale for the least physical active population

\begin{tabular}{|c|c|c|c|c|c|c|c|c|}
\hline \multirow[b]{3}{*}{ Variables } & \multirow{2}{*}{\multicolumn{2}{|c|}{ MBvOl }} & \multirow{2}{*}{\multicolumn{2}{|c|}{ MBvO2 }} & \multirow{2}{*}{\multicolumn{2}{|c|}{ Control group }} & \multirow{2}{*}{\multicolumn{2}{|c|}{$\begin{array}{l}\text { Multiple analysis of } \\
\text { variance } \\
\text { Group x Time }\end{array}$}} \\
\hline & & & & & & & & \\
\hline & $\begin{array}{l}\text { Baseline } \\
(n=98)\end{array}$ & $\begin{array}{l}\text { Post-test } \\
(\mathrm{n}=98)\end{array}$ & $\begin{array}{l}\text { Baseline } \\
(n=53)\end{array}$ & $\begin{array}{l}\text { Post-test } \\
(n=53)\end{array}$ & $\begin{array}{l}\text { Baseline } \\
(n=126)\end{array}$ & $\begin{array}{l}\text { Post-test } \\
(n=126)\end{array}$ & $F$ & $p$ Value \\
\hline Vitality Plus Scale & $39.11(7.08)$ & $39.04(7.43)$ & $37.09(7.15)$ & $40.00(6.97)$ & $38.92(6.81)$ & $38.73(6.79)$ & 5.36 & $0.01 *$ \\
\hline
\end{tabular}

*There is a difference between $\mathrm{MBvO} 2$ and $\mathrm{MBvO} 1$ and control group: post hoc test Tukey $\beta: \mathrm{p}<0.05$. The least active group are people who scored under the median of the Voorrips scale at baseline (median $=4.10$ ) 


\section{Policy implications}

Because the group of older adults is growing rapidly and the proportion of sedentary older Dutch adults is high, $\mathrm{MBvO}$ should change policies. To improve public health it is important to focus recruitment strategy on sedentary older adults as much as possible and to recommend participants to combine $\mathrm{MBvO}$ with compliance to the health enhancing physical activity guidelines.

$\mathrm{MBvO} 2(21 \%)$ than in both $\mathrm{MBvOl}(10 \%)$ and the control group $(11 \%)$. Because smoking may bias the effects of the exercise programme, an analysis was carried out to assess which outcomes were associated with smoking, and if so smoking was used as a covariate.

There were no differences between the MBvO group(s) and the control group in relation to alcohol consumption (table 1B).

\section{Adherence rate}

MBvOl subjects participated in the intervention on average 8.9 times and the $\mathrm{MBvO} 2$ subjects on average 17.8 times (adherence rate $89 \%$ in both groups).

\section{HRQoL and functional status}

No significant differences were found between time $\mathrm{x}$ group (that is, the $\mathrm{MBvOl}+\mathrm{MBvO} 2$ group compared with the control group) in the categories of HRQoL, functional status (PPT), and subjective functional status (GARS). No significant differences were found between the $\mathrm{MBvOl}$ and $\mathrm{MBvO} 2$ group that were analysed separately compared with the control group (table 2).

In the subgroups with a level of physical activity below the median at baseline, a significant improvement was found in the $\mathrm{MBvO} 2$ group on the Vitality Plus Scale $(p=0.01$, Cohen effect size 0.18 ), compared with both the MBvOl and control groups (table 3 ). No statistically significant effects were found for any other HRQoL parameters or for functional status in this sub group.

\section{DISCUSSION}

This study examined the effects of the widely implemented MBvO gymnastics programme on HRQoL and functional status of independently living older adults aged 65-80 years. People who participated once a week, the normal MBvO regimen, did not show improvement on any of the outcome measures after 10 weeks of exercise. However, in people whose physical activity was below the median at baseline and who participated in the programme twice a week an improvement was observed of HRQoL, but not in functional status.

Very few studies have evaluated the effects of community based exercise programmes in this age group. Most studies were carried out in clinical settings or were aimed at people with specific chronic diseases. ${ }^{19-22}$

Myers and Hamilton ${ }^{23}$ evaluated the Canadian Red Cross Society's Fun and Fitness Programme on the social and cognitive functioning of independently living older adults. Although the authors concluded that the exercise programme was well suited for healthy inactive older adults, once a week participation without additional regular physical activity did not improve the outcome parameters. Our study provided similar results and it seems valid to conclude that participation in MBvO-gymnastics once a week only is not sufficient to improve HRQOL and functional status in the short term. This indicates that the organisations responsible for $\mathrm{MBvO}$ in the Netherlands should endeavour to promote participation of $\mathrm{MBvO}$ at least twice a week. If this provides organisational problems-that is too few staff or insufficient adequate accommodation-MBvO participants should be encouraged to combine participation in regular $\mathrm{MBvO}$ classes with compliance to the health enhancing physical activity guidelines ${ }^{5}$ (HEPA: “.... at least 5 days a week participation in minimum of 30 minutes of moderate physical activity daily").

Hopman-Rock and Westhoff ${ }^{24}$ carried out a community intervention trial to evaluate the effectiveness of "Ageing Well and Healthily" - an exercise promotion programme in the Netherlands for older adults aged 65 years and older that lasted six weeks and contained group based health education and a low intensity exercise programme. The authors found an improvement in vitality and subjective health (measured by the RAND-36) after six weeks. However, at baseline the participants in this programme had a lower physical activity score than the MBvO population in our study and subjects continued the exercises at home for three to four times a week. The results of our study and the results of other studies confirm the theory that short term health effects of low to moderate intense exercise are more likely to be reported by the least physically active older population, because sedentary people are expected to benefit most from increasing their level of physical activity.

The protocol finally used may have caused methodological bias after randomisation. A substantial number of older adults refused to participate when they were expected to follow the MBvO gymnastics twice a week. We did not carry out an intention to treat analysis. However, at baseline the only difference between $\mathrm{MBvOl}$ and $\mathrm{MBvO} 2$ was smoking behaviour. It may be speculated about the wish of smoking $\mathrm{MBvO2}$ participants to improve their health as quickly as possible.

Studies with short term follow up have certain limitations. Older participants may take several weeks to adapt to the initial rigour of training and need a longer adaptation period to gain the optimal benefit from an exercise programme. ${ }^{28}$ This may explain why MBvO had no effect on the HRQoL and functional status. However, it is very difficult to carry out a randomised controlled intervention in the general population over a longer period of time because it is difficult to recruit a control group who are not offered the intervention as well.

De Greef et $a^{29}$ carried out a process evaluation study to compare whether the MBvO-gymnastics classes in our study were comparable to the regular MBvO gymnastics classes in the Netherlands, as evaluated by Klijnstra-Rooks. ${ }^{30}$ On the basis of this evaluation, it was discovered that the participants in our study had opinions about the characteristics of the exercise programme comparable to those of the participants of the regular $\mathrm{MBvO}$ classes. It can be concluded from this comparison that the $\mathrm{MBvO}$ classes offered in this study are ecologically valid, and that consequently the results of our study can be generalised to regular $\mathrm{MBvO}$ gymnastics classes in the Netherlands.

\section{ACKNOWLEDGEMENTS}

We would like to thank Professor H C G Kemper and Professor W L Mosterd for their role in the advisory committee for this project, J Radder, and E C P M Tak, MA, for statistical support, and Mrs M Henzen, Mrs M Wulp, MSc, Dr G Kroes (MA; Netherlands Institute for Sports and Physical Activity), Mrs W Vos (SportDrenthe), and Mrs I Jansen (Sportraad Zuid-Holland) for their organisational assistance.

\section{Authors' affiliations}

M Stiggelbout, M Hopman-Rock, TNO Prevention and Health, Leiden, Netherlands

D Y Popkema, M de Greef, Institute of Human Movement Sciences, University of Groningen, Netherlands 
W van Mechelen, Department of Social Medicine, and Institute for Research in Extramural Medicine, VU Medical Centre, Amsterdam, Netherlands

M Hopman-Rock, W van Mechelen, Body@Work Research Center Physical Activity, Work, and Health TNO-VU, Netherlands

Funding: we would like to acknowledge the Netherlands Health Research and Development Council (ZonMw), The Hague, the Netherlands, for funding this study (grant nr 2200.0062).

Conflicts of interest: none declared.

\section{REFERENCES}

1 US Department of Health and Human Services. Physical activity and health: a report of the Surgeon General. Atlanta: US Department of Health and Human Services, 1996.

2 American College of Sports Medicine. American College of Sports Medicine Position Stand. Exercise and physical activity for older adults. Med Sci Sports Exerc 1998;30:992-1008.

3 Shephard RJ. Exercise and aging: extending independence in older adults. Geriatrics 1993:48:61-4.

4 O'Brien S, Horne T. Active living among older adults: health benefits and outcomes. Philadelphia: Taylor and Francis, 1999:181-8.

5 Pate RR, Pratt M, Blair SN, et al. Physical activity and public health. A recommendation from the Centers for Disease Control and Prevention and the American College of Sports Medicine. JAMA 1995;273:402-7.

6 Kroes G, Greef de M. National initiatives for the promotion of physical activity for older persons in the Netherlands. J Aging Phys Activity 2000;8:431-5.

7 Moher D, Schulz KF, Altman DG. The CONSORT statement: revised recommendations for improving the quality of reports of parallel-group randomized trials. J Am Podiatr Med Assoc 2001;91:437-42.

8 Cohen J. Statistical power analysis for the behavioral sciences. Hillsdale, NJ: Lawrence Erlbaum, 1988.

9 de Greef M, Stevens M, Bult P, et al. GALM: Groninger Actief Leven Model: een sportstimuleringsstrategie voor sedentaire senioren. Haarlem: De Vrieseborch, 1997.

10 Lemmink K. De Groninger Fitheidstest voor ouderen: ontwikkeling van een meetinstrument. [MD thesis.] Groningen: Rijksuniversiteit Groningen, 1998.

11 Myers AM, Malott OW, Gray E, et al. Measuring accumulated health-related benefits of exercise participation for older adults: the Vitality Plus Scale. J Gerontol A Biol Sci Med Sci 1999;54:M456-66.

12 Ware JEJ, Sherbourne CD. The MOS 36-item short-form health survey (SF36). Med Care 1992;30:473-83

13 Fekkes M, Kamphuis RP, Ottenkamp J, et al. Health-related quality of life in young adults with minor congenital heart disease. Psychology and Health $2001 ; 16: 239-50$
14 Zee van der KI, Sanderman R. Het meten van de algemene gezondheidstoestand met de RAND-36: een handleiding. Groningen: Noordelijk Centrum voor Gezondheidsvraagstukken, 1993.

15 Reuben DB, Siu AL. An objective measure of physical function of elderly outpatients. The Physical Performance Test. J Am Geriatr Soc 1990;38: 1 105-12.

16 Kempen GIJM, Doeglas DM, Suurmeijer TPBM. Groningen Activiteiten Restrictie Schaal (GARS): een handleiding. Groningen: Rijksuniversitei Groningen, 1993.

17 Voorrips LE, Ravelli AC, Dongelmans PC, et al. A physical activity questionnaire for the elderly. Med Sci Sports Exerc 1991;23:974-9.

18 Konig-Zahn C, Furer JW, Tax B. Het meten van de gezondheidstoestand: algemene gezondheid. Assen: Van Gorcum, 1994:100-14.

19 Jette $A M$, Harris BA, Sleeper L, et al. A home-based exercise program for nondisabled older aldults. J Am Geriatr Soc 1996;44:644-9.

20 Ettinger-WH J, Burns R, Messier SP, et al. A randomized trial comparing aerobic exercise and resistance exercise with a health education program in older adults with knee osteoarthritis. The Fitness Arthritis and Seniors Trial (FAST). JAMA 1997;277:25-31.

21 Singh NA, Clements KM, Fiatarone MA. A randomized controlled trial of the effect of exercise on sleep. Sleep 1997;20:95-101.

22 Damush TM, Damush JGJ. The effects of strength training on strength and health-related quality of life in older adult women. Gerontologist 1999:39:705-10.

23 Myers AH, Hamilton N. Evaluation of the Canadian red cross societies fun and fitness program for seniors. Can J Aging 1982;4:201-12.

24 Hopman-Rock M. Westhoff MH. Development and evaluation of 'Aging Well and Healthily': a health education and exercise program for community-living older adults. J Aging Phys Activity 2002;10:363-80.

25 Mills KM, Stewart AL, McLellan BY. Evaluation of enrollment bias in a physical activity promotion program for seniors. J Aging Phys Activity 2001;9:398-413.

26 Hopman-Rock M, Kraaimaat FW, Biilsma JWJ. Physical activity, physical disability and osteoarthritic pain in older adults. J Aging Phys Activity 1996;4:324-37.

27 Ooijendijk WTM, Hildebrandt VH, Stiggelbout M. Trendrapport Bewegen en Gezondheid 2000-2001. Hoofddorp/Leiden: TNO Arbeid/TNO Preventie en Gezondheid, 2002.

28 American College of Sports Medicine. American College of Sports Medicine Position Stand. The recommended quantity and quality of exercise for developing and maintaining cardiorespiratory and muscular fitness, and flexibility in healthy adults. Med Sci Sports Exerc 1998;30:975-91.

29 Greef $M$ de, Popkema DH, Stiggelbout $M$, et al. Procesevaluatie MBvO effectonderzoek. In: Hopman-Rock M, Greef de M, eds. Effectevaluatie Meer Bewegen voor Ouderen-gymnastiek. Leiden/Groningen: TNO Preventie en Gezondheid; Nederlands Instituut voor Sport en Bewegen, 2002:51-6.

30 Klijnstra-Rooks A. Het eigene van MBvO gymnastieklessen aantonen. Oudfit 1994;4: 18-20. 